\title{
Comparative study of efficacy and adverse effects profile of azilsartan, olmesartan and candesartan in the control of essential hypertension
}

\author{
Zaki A. Zaman*, Hemant Kr. Sinha
}

Department of Pharmacology, Jawahar Lal Nehru Medical College, Bhagalpur, Bihar, India

Received: 31 July 2017

Revised: 14 August 2017

Accepted: 17 August 2017

*Correspondence to:

Dr. Zaki A. Zaman,

Email: zamanzakianwar@

yahoo.co.in

Copyright: () the author(s), publisher and licensee Medip Academy. This is an openaccess article distributed under the terms of the Creative Commons Attribution NonCommercial License, which permits unrestricted noncommercial use, distribution, and reproduction in any medium, provided the original work is properly cited.

\begin{abstract}
Background: Hypertension has been identified as the leading risk factor for mortality worldwide. It may lead to damage of heart, kidney, brain, vasculature and the other organs results in premature morbidity and death. The angiotensin receptor blockers are effective antihypertensive agent with excellent tolerability profiles. Azilsartan medoximil is a new ARB recently approved for treatment of hypertension. The objective of the study was to compare efficacy and tolerability of once daily treatment of the new angiotensin type1 receptor blocker (ARB) Azilsartan with Olmesartan and Candesartan.

Methods: The study was a prospective, randomized open label comparison. Total 411 patients were recruited for the study. Patients were divided into four groups. Group A comprising of 105 patients received azilsartan (40mg), Group B comprising of 106 patients received azilsartan (80mg), Group C comprising of 102 patients received olmesartan $(40 \mathrm{mg})$ and Group D comprising of 98 patients received candesartan $(12 \mathrm{mg})$. Blood pressure was monitored at base line, after 2 weeks, 4 weeks and 8 weeks of treatment.

Results: All groups were well matched in terms of age, weight, clinical findings and laboratory values. All drugs reduced both systolic blood pressure (SBP) and Diastolic blood pressure (DSP) significantly, but the reduction in SBP and DSP with azilsartan $(80 \mathrm{mg})$ was significantly greater than other drugs. The difference in BP reduction between azilsartan $(40 \mathrm{mg}$ ) and olmesartan $(40 \mathrm{mg}$ ) were not significant but both azilsartan $(40 \mathrm{mg})$ and olmesartan $(40 \mathrm{mg})$ were significantly more effective than candesartan(12mg).
\end{abstract}

Conclusions: The study indicates that azilsartan $(80 \mathrm{mg})$ is more effective in the control of hypertension than olmesartan and candesartan with similar safety profile.

Keywords: Azilsartan, Candesartan, Essential hypertension, Olmesartan

\section{INTRODUCTION}

Hypertension is a common disorder in adults around the globe and among the most common attributable causes of mortality. ${ }^{1}$ The goal of antihypertensive therapy is to maintain blood pressure of $<140 / 90 \mathrm{mmHg}$ for most people..$^{2-7}$ The angiotensin receptor blockers (ARBs) have been in clinical use since 1995 and known to be effective antihypertensive agent with excellent tolerability profiles. Azilsartan medoximil, a new generation ARB for the treatment of essential hypertension. Azilsartan was discovered through the efforts of scientists from Takeda, a Japanese pharmaceutical company by modifying the tetrazole ring present in candesartan. The chemical structure of azilsartan is very similar to the structure of candesartan and differs only by replacement of candesartan's 5 member tetrazole ring with the oxaoxadiazole ring of azilsartan. This modification makes azilsartan less acidic and more lipophilic than candesartan. Azilsartan was recently approved and has been shown to provide a more potent and sustained antihypertensive effects than other ARBs. Azilsartan medoxomil, 
olmesartan medoximil and candesartan cilexetil are prodrugs and require activation in liver in their active forms azilsartan,olmesartan and candesartan respectively. ${ }^{8,9}$ Molecular interaction of azilsartan with the AT(1) receptor and its strong inverse agonist activity towards the production of inositol phosphate(IP) could explain its strong BP lowering activity.

\section{METHODS}

\section{Study design}

We undertook randomized, open label comparative study of hypertensive patients in J.L.N. Medical college and Hospital, Bhagalpur between May 2014 to Feb 1015. Total four hundred eleven patients were recruited for this study. Patients were randomly divided into four groups. Group A comprising of 105 patients received azilsartan (40mg), Group B comprising of 106 patients received azilsartan (80mg), Group C comprising of 102 patients received olmesartan (40mg), Group D comprising of 98 patients received candesartan $(12 \mathrm{mg})$ respectively.

\section{Study procedure}

Approval of protocol and study document was taken from institutional ethical committee before study commencement. After taken written informed consent patients were screened for selection criteria.

\section{Inclusion criteria}

- $\quad$ Male and female of age between 25yrs to 55yrs.

- $\quad$ Systolic B.P between 130-169mm Hg and diastolic BP between $90-109 \mathrm{mmHg}$

\section{Exclusion criteria}

- Pregnant and lactating women

- Patients already on other antihypertensive drugs

- Patients with other condition like severe hypertension, diabetic, hepatic failure, renal failure, heart failure, acute severe asthma

- Secondary hypertension

- Chronic use of corticosteroids, NSAIDs and sex hormones like oral contraceptive pills.
A physical examination,12 lead electrocardiography and laboratory test were performed. Sitting cuff blood pressure was measured with mercury sphygmomanometer. Patients were seated for minimum of 5 minutes before the first measurement. Three recordings were taken, each separated by a minimum period of one minute. The pulse rate was measured once at the time of second blood pressure reading. Patients who met the entry criteria for the study during screening were assigned to receive a once daily dose of one of the following ARBs; 40mg or $80 \mathrm{mg}$ azilsartan, 40mg olmesartan, $12 \mathrm{mg}$ candesartan group wise. Patients in the treatment phase of the study were required to visit the clinic prior to taking their daily dose Of medication at 2, 4 and 8 week after commencing treatment. At each visit sitting cuff blood pressure was measured in triplicate, heart rate was also measured, compliance was assessed by pill count and patients were queried for adverse events.

\section{Statistical analysis}

Values are expressed as the mean \pm SD. The difference of the baseline characteristics and change in BP between groups were compared using an unpaired test. The difference between values before and after antihypertensive medication within the same group were tested using a paired t-test. $\mathrm{P}$ value $<0.05$ considered statistically significant.

\section{RESULTS}

Table 1 summarizes the baseline characteristics of the patients enrolled for this study. There were no significant differences in background factors between these groups.

The difference in blood pressure reduction after treatment with azilsartan, olmesartan and candesartan were apparent within 2 weeks. The difference in both DBP and SBP response between azilsartan (80mg) and the comparison drugs were significant for all comparisons at both 2 and 4 weeks. The difference in BP response with azilsartan (40mg) were comparable with olmesartan (40mg). Compare to candesartan (12mg), the change in BP were significant with both azilsartan (40mg) and olmesartan (40mg) (Table 2).

Table 1: Base line demographic characteristics of hypertensive patients enrolled for study.

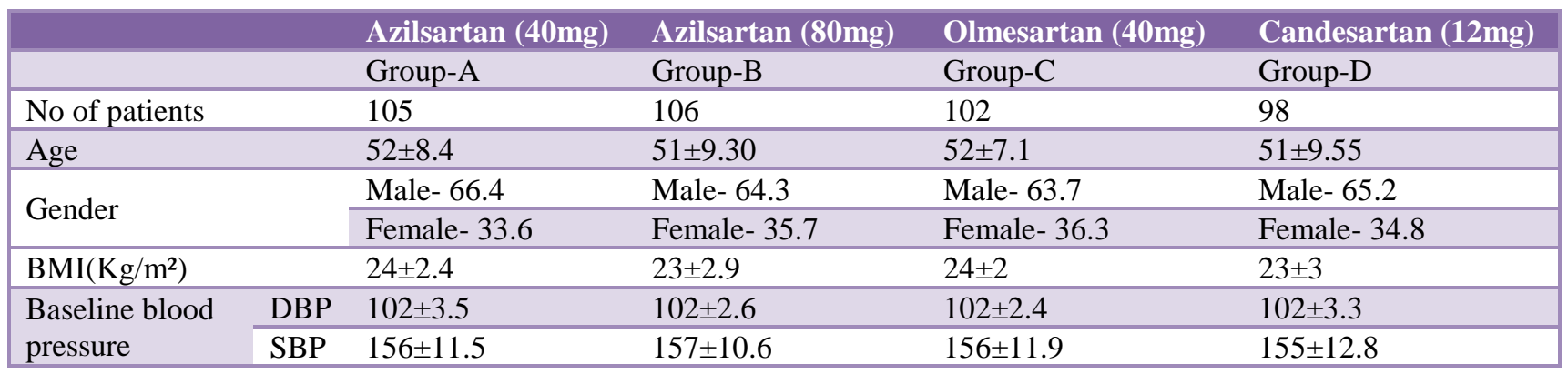


Table 2: Change in Diastolic blood pressure $(\triangle \mathrm{DBP})$ and Systolic blood pressure $(\triangle \mathrm{SBP})$ after 2 and 4 week of treatment.

\begin{tabular}{|llllll|}
\hline & & Azilsartan (40mg) & Azilsartan (80mg) & Olmesartan (40mg) & Candesartan (12mg) \\
\hline \multirow{2}{*}{ 2 weeks } & $\Delta$ DBP & -10.8 & -12.7 & -10.6 & -9 \\
\cline { 2 - 7 } & $\Delta$ SBP & -13.7 & -15.8 & -13.4 & -9.4 \\
\hline \multirow{2}{*}{4 weeks } & $\Delta$ DBP & -11.3 & -14.3 & -11.4 & -9.7 \\
\cline { 2 - 7 } & $\Delta$ SBP & -13.8 & -16.2 & -13.6 & -10.4 \\
\hline
\end{tabular}

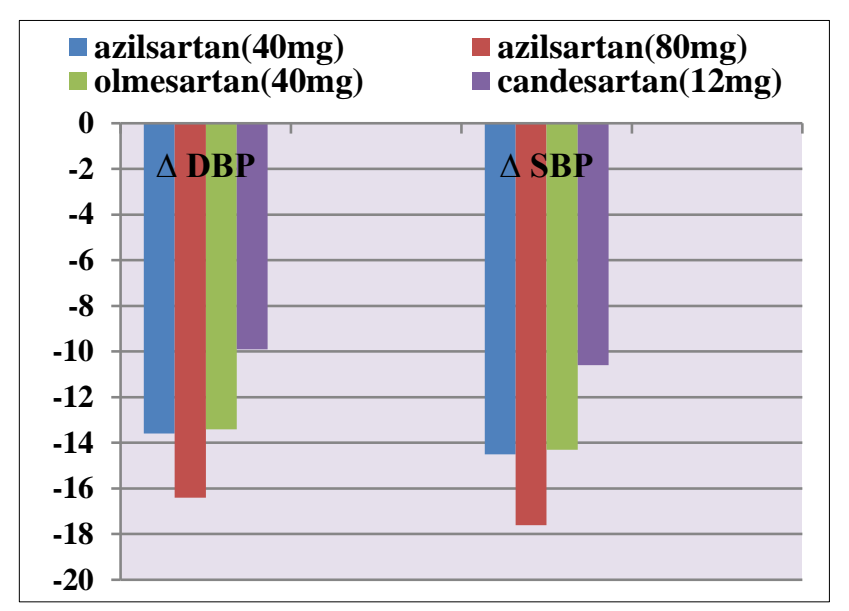

Figure 1: Change in Diastolic blood pressure ( $\triangle \mathrm{DBP})$ and Systolic blood pressure $(\triangle \mathrm{SBP})$ after 8 weeks of treatment.
Figure 1 shows, after 8 weeks of treatment the mean reduction of DBP and SBP achieved with azilsartan (80mg) was significantly greater than that with azilsartan (40mg), olmesatan (40mg) and candesartan (12mg).

The difference in BP reduction between azilsartan (40mg) and olmesartan (40mg) were not significant, but both azilsartan (40mg) and olmesartan (40mg) were significantly more effective than candesartan (12mg).

\section{Safety}

Azilsartan had a similar safety and tolerability profile to olmesartan and candesartan. Most common adverse effects were headache, dyslipidaemia and dizziness (Table 3).

Table 3: Adverse events during the treatment period.

\begin{tabular}{|c|c|c|c|c|c|}
\hline \multicolumn{2}{|c|}{ Adverse effects } & Atzilsartan (40mg) & Azilsartan (80mg) & Olmesartan (40mg) & Candesartan (12mg) \\
\hline \multicolumn{2}{|c|}{ Serious AEs, N (\%) } & 0 & 0 & 0 & 0 \\
\hline \multirow{7}{*}{$\begin{array}{l}\text { Common } \\
\text { AEs, } \\
\mathrm{N}(\%)\end{array}$} & Headache & $10(9.5)$ & $8(7.5)$ & $10(9.8)$ & $9(9.1)$ \\
\hline & Dyslipidemia & $6(5.7)$ & $4(3.7)$ & $2(1.9)$ & $2(2.04)$ \\
\hline & Dizziness & $6(5.7)$ & $8(7.5)$ & $6(5.8)$ & $4(4.08)$ \\
\hline & Diarrhoea & $2(1.9)$ & 0 & $1(0.98)$ & 0 \\
\hline & Coughing & 0 & $2(1.8)$ & $2(1.9)$ & $1(1.02)$ \\
\hline & Arthralgia & $2(1.9)$ & $2(1.8)$ & $4(3.9)$ & $6(6.12)$ \\
\hline & & $\mathrm{N}=105$ & $\mathrm{~N}=106$ & $\mathrm{~N}=102$ & $\mathrm{~N}=98$ \\
\hline
\end{tabular}

\section{DISCUSSION}

Although several previous head to head comparisons of ARBs in which clinical blood pressure was used as the primary efficacy variable have been published. ${ }^{10-15}$ Azilsartan, an angiotensin type $1\left(\mathrm{AT}_{1}\right)$ receptor blocker (ARB) was recently approved by regulatory clinical market. The development of $\mathrm{AT}_{1}$ receptor blockers (ARBs) can be traced back to the pioneer work of scientist at Takeda pharmaceutical who described a series of benzylimidazole compounds that inhibited the ability of angiotensin to stimulate the vascular contraction and increase blood pressure (BP). ${ }^{16-19}$ More than 15 years after the clinical introduction of Losartan, the FDA approved
Takeda's azilsartan medoxomil as the $8^{\text {th }}$ ARB for the treatment of hypertension. ${ }^{20}$ Azilsartan was discovered by modifying the tetrazole ring present in candesartan. ${ }^{21,22}$ Chemical structure of azilsartan is very similar to the structure of candesartan and differ only by replacement of candesartan's 5 member tetrazole ring with the 5 member oxa-oxadiazole ring of azilsartan. Unlike candesartan which must be orally administered as a prodrug candesartan cilexetil to ensure adequate bioavailability, azilsartan has been shown to be effective in reducing BP when orally administered as either the ester prodrug, azilsartan medoxomil or as the primary compound. ${ }^{23-25}$ During gastrointestinal absorption, azilsartan medoxidil is rapidly hydrolyzed to azilsartan, the bioactive molecule 
that selectively and competitively blocks angiotensin induced activation of $\mathrm{AT}_{1}$ receptor in an insurmountable fashion. $^{26,27}$ Azilsartan in clinically approved doses as azilsartan medoxomil has been shown to lower 24-hour BP in hypertensive patients significantly more than the maximum approved dose of olmesartan medoxomil, the later being considered by some to be one of the most potent ARBs for lowering BP. ${ }^{28-30}$ Given the close structural relationship between azilsartan and candesartan, head to head studies comparing the BP effects of these two drugs are of particular interest. Azilsartan 40-80mg per day lowered systolic and diastolic BP significantly more than candesartan cilexetil $(12 \mathrm{mg}){ }^{31}$ The result regarding the binding affinity of azilsartan and candesartan demonstrated that these ARBs interact with the same sites in the $\mathrm{AT}_{1}$ receptor [(Tyr (113), Lys (199), and Gln (257)] The hydrogen bonding between the oxadiazole of azilsartan- Gln (257) is stronger than that between the tetrazole of candesartan-Gln (257). ${ }^{32,33}$ An examination of the inhibition of inositol phosphate (IP) production by ARBs using contitutively active mutant receptors indicated that inverse agonist activity required azilsartanGln (257) interaction and that azilsartan had a stronger activation with Gln (257) than candesartan. There was no difference among treatment groups in the incidence of clinical and laboratory adverse events. As a class, ARBs are noted for having a side effects profile similar to that of placebo. ${ }^{33}$ A placebo group was not included in the current study, but the total adverse events rare, is similar to that reported for the placebo group in several placebo controlled trials carried out in hypertensive patients. ${ }^{34}$

\section{CONCLUSION}

This study has shown that azilsartan $(80 \mathrm{mg})$ lowered BP to a significantly greater extent than olmesartan $(40 \mathrm{mg})$ and candesartan (12mg). azilsartan (40mg) was noninferior to olmesartan (40mg). Both azilsartan $(40 \mathrm{mg})$ and olmesartan (40mg) are significantly more effective than candesartan (12mg). Azilsartan had a similar safety and tolerability profile to olmesartan and candesartan.

Funding: No funding sources Conflict of interest: None declared

Ethical approval: The study was approved by the Institutional Ethics Committee

\section{REFERENCES}

1. Data from the National Health and nutrition examination survey (NHANES). National centre for health statistics. Health, United States; 2013:34.

2. Coubian AV, Bakris GL, Black HR. The seventh report of joint National Committee on prevention, Detection, Evaluation and Treatment of high blood pressure. JAMA. 2003;289:2560-723.

3. James PA, Oparil S, Carter BL, Cushman WC, Dennison-Himmelfarb C, Handler J, et al. Evidencebased guideline for the management of high blood pressure in adults: Report from the panel members appointed to the Eighth Joint National Committee (JNC 8). JAMA. 2014 Feb;311(5):507-20.

4. Weber MA, Schiffrin EL, White WB, Mann S, Lindholm LH, Kenerson JG, et al. Clinical practice guidelines for the management of hypertension in the community. The J of Cli Hyp. 2014 Jan;16(1):14-26.

5. Mancia G, Fagard R, Narkiewicz K, Redon J, Zanchetti A, Böhm M, et al. ESH/ESC guidelines for the management of arterial hypertension: The Task Force for the Management of Arterial Hypertension of the European Society of Hypertension (ESH) and of the European Society of Cardiology (ESC). Blood pressure. 2013 Aug 1;22(4):193-278.

6. Dasgupta K, Quinn RR, Zarnke KB, Rabi DM, Ravani P, Daskalopoulou SS, et al. The 2014 Canadian Hypertension Education Program recommendations for blood pressure measurement, diagnosis, assessment of risk, prevention, and treatment of hypertension. Canadian Journal of Cardiology. 2014 May;30(5):485-501.

7. American Diabetic Association. Standard of medicinel in diabetes and hypertension. Diabetes care. 2013;36:19-25.

8. Hübner R, Högemann AM, Sunzel M, Riddell JG. Pharmacokinetics of candesartan after single and repeated doses of candesartan cilexetil in young and elderly healthy volunteers. J of Human Hyp. 1997 Sep $2 ; 11$.

9. Scott LJ, Mc Corn PL. Olmesartan medoximil. A review of its use in the management of hypertension. Drugs. 2008;68:1239-72.

10. Kassler-Taub K, Littlejohn T, Elliott W, Ruddy T, Adler E. Comparative efficacy of two angiotensin II receptor antagonists, irbesartan and losartan, in mildto-moderate hypertension. Ame J of hyp. 1998 Apr;11(4):445-53.

11. Hedner T, Oparil S. A comparison of angiotensin antagonists Valsartan and Losartan in the treatment of essential hypertension. Am J Hypertens. 1992;12:4147.

12. Millan JH, Siche JP. ABPM comparison of the hypertensive profile of the selective angiotensin-2 receptor antagonists telmisartan and losartan in patients of mild to moderate hypertension. J Hum Hypertens. 1999;13:657-64.

13. Diament M, Idema RN. The use of Fourier analysis in the calculation of trough and peak ratio from ambulatory blood pressure measurement J Hum Hypertens. 1998;12:61-7.

14. Andersen OK, Neldam $S$. The antihypertensive effects and tolarebility of Candesartan Cilexetil. A new angiotensin-2 receptor antagonist, in comparison with losartan. Blood Press. 1998;7:53-50.

15. Oparil S, Guthrie R, Lewin AJ, Marbury T, Reilly K, Triscari J, et al. Irbesartan/Losartan Study Investigators. An elective-titration study of the comparative effectiveness of two angiotensin IIreceptor blockers, irbesartan and losartan. Clinical therapeutics. 1998 May;20(3):398-409. 
16. Ram CV. Angiotensin receptor blockers: Current status and future prospects. Am J Med. 2008;12:65663.

17. Furukawa Y, Kishimoto S, Nishikawa K, inventors. Takeda Chemical Industries, Ltd, Osaka, Japan, assignee. US Patent. Hypotensive imidazole-5-acetic acid derivatives. 1982 October 20;355:040.

18. Furukawa Y, Kishimoto S, Nishikawa K, inventors. Takeda Chemical Industries, Ltd., Osaka, Japan, assignee. US Patent 4. Hypotensive imidazole derivatives. 1982 July 20;340:598.

19. Duncia JV, Chiu AT, Carini DJ, Gregory GB, Johnson AL, Price WA, et al. The discovery of potent nonpeptide angiotensin II receptor antagonists: a new class of potent antihypertensives. Journal of medicinal chemistry. 1990 May;33(5):1312-29.

20. Takeda Pharmaceuticals North America. Edarbi prescribing information. 2011.

21. Kohara Y, Imamiya E, Kubo K, Wada T, Inada Y, Naka T. A new class of angiotensin II receptor antagonists with a novel acidic bioisostere. Bioorganic Medicinal Chemistry Letters. 1995;5(17):1903-8.

22. Kohara Y, Kubo K, Imamiya E, Wada T, Inada Y, Naka T. Synthesis and angiotensin II receptor antagonistic activities of benzimidazole derivatives bearing acidic heterocycles as novel tetrazole bioisosteres. J Med Chem. 1996;39(26):5228-35.

23. Rakugi H, Enya K, Sugiura K, Ikeda Y. Comparison of the efficacy and safety of azilsartan with that of candesartan cilexetil in Japanese patients with grade III essential hypertension: a randomized, double-blind clinical study. Hypertens Res.; 2012.

24. Naka T, Kubo K. A new class of diacidic nonpeptide angiotensin II receptor antagonists: candesartan cilexetil. Curr Pharm Des. 1999;5(6):453-72.

25. Baker WL, White WB. Azilsartan medoxomil: A new angiotensin II receptor antagonist for treatment of hypertension. Ann Pharmacother. 2011;45(12):150615

26. Ojima M, Igata H, Tanaka M, Sakamoto H, Kuroita T, Kohara Y, et al. In vitro antagonistic properties of a new angiotensin type 1 receptor blocker, azilsartan, in receptor binding and function studies. Journal of Pharmacology and Experimental Therapeutics. 2011 Mar 1;336(3):801-8.

27. Kusumoto K, Igata H, Ojima M, Tsuboi A, Imanishi M, Yamaguchi F, et al. Antihypertensive, insulin- sensitising and renoprotective effects of a novel, potent and long-acting angiotensin II type 1 receptor blocker, azilsartan medoxomil, in rat and dog models. European journal of pharmacology. 2011 Nov 1;669(1):84-93.

28. Zannad F, Fay R. Blood pressure-lowering efficacy of olmesartan relative to other angiotensin II receptor antagonists: an overview of randomized controlled studies. Fundam Clin Pharmacol. 2007;21(2):181-90.

29. Sica D, White WB, Weber MA, Bakris GL, Perez A, $\mathrm{Cao} \mathrm{C}$, et al. Comparison of the novel angiotensin II receptor blocker azilsartan medoxomil vs valsartan by ambulatory blood pressure monitoring. The Journal of Clinical Hypertension. 2011 Jul 1;13(7):467-72.

30. White WB, Weber MA, Sica D, Bakris GL, Perez A, Cao $C$, et al. Effects of the angiotensin receptor blocker azilsartan medoxomil versus olmesartan and valsartan on ambulatory and clinic blood pressure in patients with stages 1 and 2 hypertension. Hypertension. 2011;57(3):413-20.

31. Bakris GL, Sica D, Weber M, White WB, Roberts A, Perez A, et al. The comparative effects of azilsartan medoxomil and olmesartan on ambulatory and clinic blood pressure. The Journal of Clinical Hypertension. 2011 Feb 1;13(2):81-8.

32. Zaiken K, Cheng JW. Azilsartan medoxomil: a new angiotensin receptor blocker. Clin Ther. 2011;33(11):1577-89.

33. Mazzolai L, Burnier M. Comparative safety and tolerabilityof angiotensin II receptor antagonists. Drug Saf. 1999;21:23-33.

34. Lacourciere Y, Asmar R. A comparison of the efficacy andduration of action of candesartan cilexetil and losartan as assessed by clinic and ambulatory blood pressure after a missed dose, in truly hypertensive patients. A placebo-controlled, forced titration study. Am J Hypertens. 1999;12:1181-7.

Cite this article as: Zaman ZA, Sinha HK. Comparative study of efficacy and adverse effects profile of azilsartan, olmesartan and candesartan in the control of essential hypertension. Int J Basic Clin Pharmacol 2017;6:2140-4. 